\title{
Wpływ kryzysu gospodarczego na politykę klimatyczną Unii Europejskiej i jej konsekwencje dla polskiego przemysłu energetycznego oraz zagospodarowania przestrzennego Polski
}

\section{The influence of the economic crisis on the European Union's climate policy and its consequences for the Polish power industry and land use in Poland}

\begin{abstract}
Streszczenie: Regulacje klimatyczne Unii Europejskiej obciążają polską energetykę w sposób nieproporcjonalny do innych państw, głównie ze względu na dominację węgla w strukturze paliw zużywanych do produkcji energii w Polsce. Skutki globalnego kryzysu gospodarczego, wywołanego w 2007 roku w USA mogą zmienić kształt polityki klimatycznej w Europie, a tym samym przyczynić się do zmian kierunków rozwoju polskiego przemysłu energetycznego i zagospodarowania przestrzennego kraju. Niniejszy artykuł stanowi próbę projekcji konsekwencji prowadzenia polityki energetycznej przez Polskę na sytuację polskiego przemysłu energetycznego oraz stan zagospodarowania przestrzennego kraju. W artykule rozpatrzono trzy możliwe warianty dotyczące kształtu przyszłej polityki energetycznej dla Polski: 1) kontynuację aktualnej polityki, 2) jej złagodzenie, 3) jej zaostrzenie.

Kontynuacja obecnej polityki klimatycznej w ciągu najbliższych lat sprawi, że udział węgla w strukturze paliwowej polskiej elektroenergetyki ulegnie zmniejszeniu. Nastąpi wzrost roli odnawialnych źródeł energii (OZE), a niemal połowa tego typu energii będzie wytwarzana przez energetykę wiatrową, głównie ze względu na relatywnie dogodne w tym względzie warunki geograficzne Polski. Dla zapewnienia efektywnego działania nowych instalacji istnieje potrzeba rozbudowy infrastruktury energetycznej, w szczególności sieci przesyłowych wewnątrz kraju oraz łączących go z państwami sąsiednimi: Niemcami, Słowacją, Litwą i Ukrainą. Powinna nastąpić także integracja ze skandynawskimi systemami energetycznymi.

W sytuacji złagodzenia polityki klimatycznej Unii Europejskiej w obliczu kryzysu ekonomicznego kosztowne inwestycje redukujące emisję $\mathrm{CO}_{2}$ zostaną odroczone. Wówczas pewna jest dominacja węgla kamiennego i brunatnego w strukturze zużycia paliw w polskiej energetyce, z uwagi na jego względnie niski koszt oraz wysoką wydajność energetyczną. Elektrownie węglowe będą osiągać wysokie wyniki finansowe. Elektrownie gazowe będą stosowane głównie jako wsparcie w okresach
\end{abstract}


szczytowych zużycia energii. Produkcja energii z OZE, biomasy oraz biogazu nie będzie wymuszana. Energetyka jądrowa nie będzie proponowana.

W sytuacji zaostrzenia polityki klimatycznej polski sektor węglowy będzie wypierany przez inne źródła energii, w szczególności przez odnawialne. Do osiągnięcia tego efektu przyczynią się uregulowania prawne poprawiające atrakcyjność inwestowania $\mathrm{w}$ instalacje wykorzystujące OZE, przy jednoczesnym obniżeniu rentowności elektrowni konwencjonalnych poprzez rosnące ceny uprawnień do emisji $\mathrm{CO}_{2}$, np. zatwierdzenie planu Komisji Europejskiej w sprawie tzw. blackloadingu, wejście do polskiego porządku prawnego tzw. małego trójpaku energetycznego oraz projektu tzw. dużego trójpaku energetycznego. Polityka dekarbonizacji będzie sprzyjała rozwojowi energetyki jądrowej oraz produkcji energii z OZE. Zbyt restrykcyjna polityka klimatyczna w polskich realiach może doprowadzić do degradacji gospodarki, ponieważ wzrost cen energii wpłynie na wzrost kosztów działalności większości przedsiębiorstw. Z drugiej jednak strony, pod pewnymi warunkami stworzonymi przez odpowiednie prawa i instytucje, alokacja zasobów w sektorach technologii niskoemisyjnych może spowodować rozwój innowacji, wzrost gospodarczy i powstawanie nowych miejsc pracy, m.in. w sektorze produkcji urządzeń dla sektora energetycznego, w firmach budowlano-montażowych, w rolnictwie energetycznym, w obszarze pozyskiwania i przetwarzania biomasy i paliw. Dekarbonizacja może okazać się korzystna dopiero w dalekiej przyszłości.

Nadchodząca roczna prezydencja Polski w międzynarodowej konwencji klimatycznej może stać się poważnym impulsem do wzmocnienia polskiego stanowiska oraz szansą na przeforsowanie regulacji korzystnych dla polskiego przemysłu energetycznego.

Abstract: Climate Regulations imposed by the European Union affect the Polish energy sector unequally, compared to other countries, mainly due to the dominance of coal as main resource in energy production. The effects of the global economic crisis, which started in 2007 in the United States, could change the climate policy in Europe, and thus contribute to changing the direction of Polish power industry development and spatial development of the country.

Continuing with the current climate policy in the upcoming years will cause the reduction of the use of coal in the fuel structure of Polish power industry. The role of renewable energy will increase and almost half of this type of energy will be produced by wind power, mainly due to the geographical location of Poland. To ensure the effectiveness of the new systems, proper infrastructure needs to be developed, in particular transmission networks within the country, as wells as connections with neighbouring countries: Germany, Slovakia, Lithuania and Ukraine. Moreover, it is desirable to integrate with the Nordic energy systems. The powers-that-be in coal industry for several years now have attempted to save conventional energy by implementing projects reducing the risk associated with investments in the coal sector and supporting marketing campaigns that promote Polish coal. Nowadays, research and development centres are working on various applications for modern clean power generation technologies, which base on solids that limit greenhouse gas emissions.

In the case of easing on the climate policy of the EU as a result of the global economic crisis, expensive investments reducing $\mathrm{CO}_{2}$ emission would be deferred. In such a case, the domination of coal and lignite in Polish energy sector is inevitable, due to its relatively low cost and high energy efficiency. Coal plants would be in good financial shape. Gas power plants would be mainly used as support during periods of peak energy consumption. The production of renewable energy, biomass and biogas would not be enforced. Nuclear power would not be proposed.

In the case of strict climate policy, Polish coal sector would be replaced by other energy sources, in particular renewables. To achieve this effect, regulations enhancing the attractiveness of investing in installations using renewable energy sources would be introduced, while the profitability of conventional power plants would be reduced by raising the price of $\mathrm{CO}_{2}$ emission allowances, such as the European Commission's approval of the plan of black loading, implementation into the Polish legal system a "small triple energy package", and a "big triple energy package". Decarbonisation policy would enable the development of nuclear energy and the production of energy from renewable sources. In Polish conditions, a climate policy that is too restrictive may lead to degradation of economy, as an 
increase in the price of energy would result in an increase of operational costs for most companies. On the other hand, under certain conditions created by the relevant laws and institutions, the allocation of resources in sectors of low carbon technologies could lead to the development of innovative technologies, economic growth, and job creation, for example in the production of equipment for the energy sector, in construction and assembly companies, energetic agriculture, in the acquiring and processing of biomass fuels. Decarbonisation may be beneficial only in the distant future.

The upcoming year-long Polish Presidency at the International Climate Convention could be a major opportunity to strengthen the Polish position and a chance to enforce the regulations favourable to the Polish energy industry.

Słowa kluczowe: bezpieczeństwo energetyczne; kryzys gospodarczy; odnawialne źródła energii; polityka klimatyczna; Unia Europejska

Keywords: energetic independence; economic crisis; renewable energy; climate policy; European Union

\section{WSTĘP}

Regulacje klimatyczne Unii Europejskiej mocno wpływają na kierunek rozwoju polskiej energetyki. Dotyczy to nie tylko źródeł konwencjonalnych i odnawialnych, ale również energetyki jądrowej i gazownictwa. Obecnie Polska musi wyjść naprzeciw wyzwaniom, jakie niosą zasady zrównoważonego rozwoju i polityki klimatycznej Unii Europejskiej. Przez europejskich polityków coraz głośniej propagowana jest stopniowa dekarbonizacja gospodarki, a wynikające z niej zaostrzone limity emisyjne obciążają polską energetykę i gospodarkę w sposób nieproporcjonalny do obciążeń innych państw Europy, ze względu na kilka czynników. Najważniejszym z nich jest ograniczenie możliwości rozwoju energetyki konwencjonalnej, głównie węglowej, na której opiera się polska energetyka. Niedostateczny stopień rozwoju infrastruktury energetycznej, zwłaszcza sieci przesyłowych i rozdzielczych, oraz zużycie urządzeń energetycznych również utrudniają dostosowanie się do unijnych wymogów. Problem potęguje niestabilna sytuacja zarówno na rynku cen energii, jak i w obszarze regulacji prawnych w przemyśle energetycznym, które zniechęcają zagranicznych inwestorów do powierzania kapitału przedsiębiorstwom działającym na terenie Polski. Z tych samych powodów zahamowany jest rozwój energetyki odnawialnej, który potrzebuje sporych nakładów inwestycyjnych.

Zmiany w sektorze energetycznym wymagają również aprobaty społeczeństwa, mającego wpływ na zagospodarowanie przestrzenne polskiego terytorium. Taka sytuacja nie tylko nie sprzyja spełnieniu wymogów narzuconych przez Unię Europejską, ale może także stanowić poważne zagrożenie dla bezpieczeństwa energetycznego kraju. Skutki globalnego kryzysu gospodarczego, wywołanego w 2007 roku w Stanach Zjednoczonych przez załamanie na rynku kredytów hipotecznych subprime, mogą jednak zmienić oblicze polityki klimatycznej w Europie, a tym samym przyczynić się do zmian kierunków rozwoju polskiego przemysłu energetycznego i zagospodarowania przestrzennego kraju. 
Celem niniejszej publikacji jest przedstawienie możliwych scenariuszy kształtowania się polityki klimatycznej Unii Europejskiej pod wpływem światowego kryzysu gospodarczego oraz ich potencjalnych skutków dla polskiego przemysłu energetycznego do roku 2050, a także zasygnalizowanie niezbędnych zmian w zagospodarowaniu przestrzennym Polski. Źródłami informacji są dokumenty wydane przez instytucje państwowe i międzynarodowe (m.in. Koncepcja przestrzennego zagospodarowania kraju 2030, 2012; Konkluzje Rady Europejskiej, 2007; Konkluzje Rady Europejskiej, 2011), artykuły naukowe dotyczące geografii przemysłu (Płaziak, 2013a; Płaziak, 2013b; Rachwał, 2008; Zioło, 2008) oraz opracowania z zakresu energetyki (Szybalski, 2013; Okulski, 2012; Jankowski, 2011; Tajduś, Czaja, Kasztelewicz, 2011) i polityki klimatycznej (Szlagowski, 2012; Kasztelewicz, 2011).

\section{PROBLEM EMISJI GAZÓW CIEPLARNIANYCH}

Ocieplanie się klimatu Ziemi przedstawiane jest przez niektórych polityków jako niekwestionowany fakt, udowodniony przez klimatologów. Wedle badań naukowych w porównaniu z początkiem XX wieku temperatura naszej planety wzrosła o $0,8^{\circ} \mathrm{C}$, a największy wzrost odnotowano po 1980 roku (Szlagowski, 2012). Zbadanie temperatur na całej powierzchni Ziemi wydaje się zabiegiem niemożliwym ze względu na nierównomierny rozkład stacji meteorologicznych oraz dużą zmienność warunków pogodowych w skali globalnej. Poważnych problemów może przysporzyć również sama analiza otrzymanych wyników, ponieważ trudno wskazać właściwą jej metodologię. Abstrahując od tych wątpliwości, zwolennicy teorii ocieplania klimatu Ziemi wymieniają wiele czynników zewnętrznych odpowiedzialnych za taki stan rzeczy, mianowicie: zmiany aktywności słonecznej, erupcje wulkanów czy przesunięcia orbity Ziemi względem Słońca. Jednak zdecydowana większość komentatorów twierdzi, że do ocieplenia klimatu w największym stopniu przyczynia się rosnący udział gazów cieplarnianych w atmosferze, głównie: pary wodnej $\left(\mathrm{H}_{2} \mathrm{O}\right)$, dwutlenku węgla $\left(\mathrm{CO}_{2}\right)$, metanu $\left(\mathrm{CH}_{4}\right)$, podtlenku azotu $\left(\mathrm{N}_{2} \mathrm{O}\right)$. Ich stężenie wyznacza nierównowaga pomiędzy źródłami oraz pochłaniaczami. Do głównych źródeł związanych z aktywnością człowieka należą: spalanie paliw kopalnych, wylesienie, działalność rolnicza związana z hodowlą i wykorzystaniem nawozów, działalność przemysłowa, oraz wykorzystywanie chlorofluorowęglanów w urządzeniach chłodniczych.

Udział emisji samego $\mathrm{CO}_{2}$ w efekcie cieplarnianym szacuje się na ok. 25\%. Naturalne źródła emisji $\mathrm{CO}_{2}$ uwalniają 20-krotnie więcej tego gazu w porównaniu do źródeł antropogenicznych. Interesujący jest jednak fakt, że bilans w przypadku naturalnych źródeł ma zwykle charakter negatywny (pochłaniają one więcej $\mathrm{CO}_{2}$, niż uwalniają), co oznacza, że obecnie przyroda nie jest w stanie pozostać w równowadze bez działalności człowieka (Szlagowski, 2012).

Z uwagi na prezentowane wnioski o negatywnym wpływie działalności człowieka na klimat podnoszą się coraz śmielsze głosy o tym, że powinien on zostać zminimalizowany, a zagospodarowanie przestrzeni związane $\mathrm{z}$ rozwojem gospodarczym powinno w najmniejszym 
możliwym stopniu naruszać środowisko naturalne. Należy to zrobić dla zapewnienia zrównoważonego rozwoju oraz dobrej jakości życia przyszłych pokoleń.

W Polsce emituje się rocznie gazy cieplarniane w ilości ok. $400 \mathrm{mln}$ ton ekwiwalentu $\mathrm{CO}_{2}$ rocznie (tab. 1).

Tab. 1. Źródła emisji gazów cieplarnianych w polskim przemyśle

\begin{tabular}{|l|c|}
\hline \multicolumn{1}{|c|}{ Źródło emisji } & $\begin{array}{c}\text { Ilość emitowanych gazów cieplarnianych } \\
\text { (w mln ton) }\end{array}$ \\
\hline produkcja energii i ciepła & 250 \\
\hline procesy przemysłowe & 50 \\
\hline transport & 35 \\
\hline rolnictwo & $>30$ \\
\hline
\end{tabular}

Źródło: opracowanie własne na podstawie: Szlagowski, 2012

W przytoczonych powyżej sektorach można poszukiwać możliwości obniżania emisji $\mathrm{CO}_{2}$ w pierwszej kolejności. Obniżenie to można uzyskać poprzez:

- zwiększanie efektywności wytwarzania i przesyłania w istniejących technologiach,

- zwiększanie stopnia skojarzenia produkcji energii elektrycznej i ciepła,

- zmiany paliwa na mniej emisyjne,

- wprowadzanie nowych technologii wytwarzania,

- wychwytywanie i składowanie $\mathrm{CO}_{2}$.

\section{Polityka KLIMATyCZNO-ENERgetyczNa UniI EUROPEJSKIEJ}

Zmiany w strukturze przemysłu zachodzą pod wpływem różnorodnych uwarunkowań międzynarodowych i krajowych. Impulsy pochodzące z otoczenia międzynarodowego związane są m.in. z procesami integracji państw i regionów (Rachwał, 2008; Zioło, 2008), a jednym z efektów integracji europejskiej dla Polski, w kontekście prawnych uwarunkowań w przemyśle energetycznym, jest polityka energetyczno-klimatyczna Unii Europejskiej (Ferudun, Wilczyński, 2013). Została ona zdefiniowana przez kilka dokumentów. Najważniejszą podstawą prawną przyczyniającą się do rozpoczęcia realizacji działań zmierzających do powstrzymania zmian klimatu w skali światowej była ramowa konwencja Organizacji Narodów Zjednoczonych w sprawie zmian klimatu (UNFCCC) (United Nations Framework Convention on Climate Change, 1992), którą podpisano w 1992 r. na Międzynarodowej Konferencji ONZ w Rio de Janeiro, dotyczącej wpływu rozwoju przemysłu na środowisko. Jej celem było ustabilizowanie tempa emisji gazów cieplarnianych w takim stopniu, aby ekosystemy w sposób naturalny mogły przystosować się do zachodzących zmian klimatu. Sygnatariusze konwencji postanowili, że podobne spotkania będą odbywać się raz w roku.

Trzecia Konferencja Stron Konwencji (COP - Conference of the Parties), która miała miejsce w 1997 roku w Kioto, zaowocowała podpisaniem międzynarodowego porozumienia 
w sprawie przeciwdziałania globalnemu ociepleniu. Sygnatariusze protokołu (Kyoto Protocol to the United Nations Framework Convention on Climate Change, 1998) - państwa uprzemysłowione - zobowiązali się do 2012 roku obniżyć emisję 6 gazów cieplarnianych do ok. 5\% w porównaniu do poziomu z roku 1990 (Hermann, 1998). Protokół z Kioto wprowadził również kilka mechanizmów regulujących w istotny sposób funkcjonowanie światowych rynków energetycznych. Pierwszy z nich - mechanizm wspólnych wdrożeń (Joint Implementation) - polega na inwestowaniu przez kraje wysoko rozwinięte w krajach o niższych kosztach redukcji emisji. Za uzyskaną w ten sposób redukcję kraj inwestujący otrzymuje odpowiednią liczbę jednostek ERU (Emission Reduction Unit - jednostki emisji unikniętej, czyli takiej, która dzięki zastosowaniu nowego rozwiązania technicznego lub technologicznego albo innych surowców czy też paliw, nie została wprowadzona do atmosfery). W ten sposób kraj objęty limitem emisji, pragnący wdrożyć na swoim terenie inwestycję obniżającą emisję gazów cieplarnianych, ma możliwość znalezienia odpowiedniego partnera, który w zamian za sfinansowanie inwestycji otrzymuje dodatkowe uprawnienia do emisji. Drugi - mechanizm czystego rozwoju (Clean Development Mechanism) - ma zachęcić kraje rozwinięte do finansowania inwestycji redukujących emisję w krajach rozwijających się, na które nie został nałożony limit emisji. Inwestor otrzymuje w zamian CER (Certified Emission Reduction Unit jednostka poświadczonej redukcji emisji). Celem kolejnego - mechanizmu handlu emisjami (Emission Trading) - jest umożliwienie sprzedaży i zakupu pozwoleń na emisję pomiędzy krajami i instalacjami. Każdy kraj - strona lub instalacja otrzymuje określoną liczbę jednostek dopuszczalnej emisji EUA (European Union Allowances), z których każda uprawnia do emisji 1 tony $\mathrm{CO}_{2}$. EUA przyznawane są przez państwo w tzw. Krajowym Planie Rozdziału Uprawnień (National Allocation Plan) podmiotom objętym systemem kilkuletniego okresu rozliczeniowego (2005-2007, 2008-2012, 2013-2020), przy czym wysokość uprawnień $\mathrm{z}$ roku na rok ulega zmniejszeniu. Jednostki te są przedmiotem handlu na zasadach wolnego rynku. Przedsiębiorstwo porównuje koszt redukcji emisji w swoich instalacjach z ceną zakupu uprawnień do emisji na rynku. W ten sposób mechanizm ma zmuszać kraje (przedsiębiorstwa) do redukcji emisji $\mathrm{CO}_{2}$. Ostatni z mechanizmów - mechanizm aktywizacji absorpcji $\mathrm{CO}_{2}$ przez rośliny (Land Use Change and Forestry) - ma przyczynić się do zwiększenia udziału roślin w procesie redukcji emisji, na przykład poprzez zalesienie. Kraj podejmujący takie działania otrzymuje w zamian jednostki RMU (Removal Unit).

W celu zabezpieczenia realizacji założeń Protokołu z Kioto Unia Europejska wprowadziła do porządku prawnego szereg regulacji. W marcu 2006 roku Komisja Europejska opublikowała zieloną księgę (Green Paper), w której określono priorytetowe działania w sektorze energetycznym, a wśród nich wymieniono: walkę ze zmianami klimatu, zapewnienie bardziej zrównoważonej, efektywnej i zróżnicowanej energii oraz strategiczny plan wdrożenia nowych technologii w dziedzinie energetyki. W dokumencie tym po raz pierwszy wskazano technologię CCS (Carbon Capture and Sortage - system wychwytywania i składowania $\mathrm{CO}_{2}$ ) jako jedną z istotnych w kontekście redukcji $\mathrm{CO}_{2}$. Na początku 2007 roku Komisja Europejska zaprezentowała oficjalnie dokument pt. Europejska polityka energetyczna (Komunikat Komisji do Rady Europejskiej i Parlamentu Europejskiego, 2007), w którym 
zawarto propozycje strategicznych kierunków rozwoju polityki energetycznej. Ustalono w nim następujące cele dla Unii Europejskiej:

- wewnętrzna redukcja emisji gazów cieplarnianych o minimum $20 \%$, niezależnie od sytuacji, w stosunku do poziomu z 1990 roku, której najważniejszym narzędziem realizacji miał być mechanizm handlu uprawnieniami do emisji - EU ETS,

- zwiększenie udziału energii odnawialnej w łącznym bilansie energetycznym Unii Europejskiej z istniejącego poziomu poniżej 7\% do 20\% w roku 2020 oraz osiągnięcie przynajmniej $10 \%$ udziału biopaliw,

- poprawa efektywności energetycznej, a jako jej skutek - ograniczenie łącznego zużycia energii pierwotnej o $20 \% \mathrm{w}$ roku 2020, w porównaniu do prognozy zapotrzebowania na paliwa i energię.

Polsce zaproponowano zwiększenie udziału energii z odnawialnych źródeł energii do 15\% w 2020 roku, zamiast 20\%, z uwagi na mniejsze zasoby i efektywność OZE. Pakiet ten (zwany skrótowo pakietem „3x20\%” lub „20/20/20”) został w marcu 2007 roku przyjęty przez Parlament Europejski i przywódców państw członkowskich Unii Europejskiej.

Na uwagę zasługuje fakt, że główne założenia polityki Unii Europejskiej dotyczącej sektora energetycznego zostały wprowadzone jeszcze przed kryzysem gospodarczym w Europie, a do jej pozostałych celów należą:

- osiągnięcie międzynarodowego porozumienia w sprawie obniżenia emisji gazów cieplarnianych w krajach rozwiniętych o 30\% w roku $2020 \mathrm{w}$ stosunku do poziomu z roku 1990, a globalnie w roku 2050 zmniejszenie emisji maksymalnie o 50\% w stosunku do roku 1990, w celu ograniczenia globalnego ocieplenia o $2{ }^{\circ} \mathrm{C}$,

- poprawa bezpieczeństwa energetycznego Unii Europejskiej jako całości oraz poszczególnych państw członkowskich,

- ustalenie ram czasowych wprowadzenia obowiązku stosowania systemów CCS dla elektrowni węglowych i gazowych,

- implementacja strategicznego planu w dziedzinie technologii energetycznych, który pozwoli na obniżenie kosztu czystej energii (najpierw OZE i CCS, a w perspektywie roku 2050 energetyki wodorowej, jądrowej i termojądrowej), zwiększenie efektywności energetycznej budynków, urządzeń i procesów przemysłowych oraz systemów transportu,

- rozwój unijnych ram dla energetyki jądrowej, przy spełnieniu najwyższych standardów bezpieczeństwa, z uwzględnieniem gospodarki odpadami jądrowymi i zamykania obiektów jądrowych,

- prowadzenie przez Unię Europejską aktywnej i wspólnej dla państw członkowskich polityki zagranicznej w zakresie energetyki.

Ponadto w lutym 2011 roku Rada Europejska zatwierdziła bezpośrednie cele dotyczące redukcji emisji gazów cieplarnianych. W Konkluzjach Rady Europejskiej z 2011 roku napisano:

„Rada Europejska oczekuje opracowania strategii rozwoju niskoemisyjnego na okres do roku 2050, zapewniającej ramy długoterminowych działań w sektorze energetycznym i w innych powiązanych sektorach. Osiągnięcie uzgodnionego w październiku 2009 roku przez państwa rozwinięte jako grupę, w kontekście koniecznych redukcji zgodnie 
z ustaleniami Międzyrządowego Zespołu ds. Zmian Klimatu (Intergovernmental Panel on Climate Change), unijnego celu polegającego na zredukowaniu do roku 2050 emisji gazów cieplarnianych o 80-95\% w stosunku do roku 1990 będzie wymagało rewolucyjnych zmian w systemach energetycznych, zmian, które muszą zacząć się już teraz. Powinno się rozważyć, czy nie należałoby ustalić etapów pośrednich na drodze do realizacji celu na rok 2050. Rada Europejska będzie regularnie analizować rozwój wypadków." (Konkluzje Rady Europejskiej, 2011, EUCO 2/1/11, REV 1: 6).

\section{KONTYNUACJA OBECNEJ POLITYKI KLIMATYCZNEJ}

Obecnie dominującym paliwem w strukturze polskiej elektroenergetyki jest węgiel, jednak - na skutek realizowanej polityki klimatycznej Unii Europejskiej - jego rola jako podstawowego źródła energii z roku na rok ma wykazywać tendencję malejącą. Według Koncepcji przestrzennego zagospodarowania kraju 2030 (KPZK 2030), udział tego paliwa w produkcji energii elektrycznej obniży się z 92\% w 2006 roku do niecałych 57\% w 2030 roku. Zaobserwujemy wzrost roli OZE w produkcji energii elektrycznej - do ok. 19\%, a niemal połowa (45\%) tego typu energii będzie wytwarzana przez energetykę wiatrową. Tym planom przeczą jednak wyniki analiz polskiego rynku energetycznego przeprowadzone przez Bank Światowy oraz specjalistyczne firmy, m.in. Ernst\&Young, McKinsey, EnergSys, a także Instytut im. E. Kwiatkowskiego, które niemal jednoznacznie świadczą o braku możliwości sprostania unijnym wytycznym. Na przeszkodzie stoją problemy polskiej energetyki, a wśród nich: wysokie zapotrzebowanie na energię, nieadekwatny poziom rozwoju infrastruktury wytwórczej i transportowej paliw i energii, znaczne uzależnienie od zewnętrznych dostaw gazu ziemnego i niemal całkowite - od zewnętrznych dostaw ropy naftowej. Barierą może okazać się niepewność regulacyjna na rynku energetycznym dotycząca m.in. obszaru energetyki odnawialnej, braku ścisłej metodologii kalkulacji taryf oraz decyzji o całościowej liberalizacji w segmencie sprzedaży energii elektrycznej, a także braku zdecydowanych działań legislacyjnych związanych z systemem wsparcia wysokosprawnej kogeneracji. Wszystkie te czynniki w znaczącym stopniu zwiększają poziom ryzyka inwestycyjnego, a tym samym zniechęcają inwestorów do realizacji projektów w polskiej energetyce, utrudniając (lub nawet uniemożliwiając) realizację założeń $K P Z K 2030$.

Zwiększanie produkcji energii z OZE - do poziomu co najmniej 15\% w 2020 roku - jest jednym z najważniejszych elementów polityki klimatycznej UE. Należy tutaj zaznaczyć, iż w związku z tym, zgodnie z dyrektywą unijną dotyczącą charakterystyki energetycznej budynków (dyrektywa Parlamentu Europejskiego i Rady 2010/31/UE), do roku 2020 wszystkie budynki oddane do użytkowania mają mieć nie tylko charakter domów energooszczędnych, ale energia służąca do ich ogrzewania i pozyskania ciepłej wody w znacznym stopniu będzie musiała pochodzić z OZE i zostać wytworzona na miejscu lub w pobliżu. Będzie to związane $\mathrm{z}$ dodatkowymi kosztami w zakresie technologii budowy domów, ale też budowy miejscowych przydomowych elektrowni (Płaziak, 2013a; Płaziak, 2013b). 
Osiągnięcie tego celu mają zapewnić inwestycje publiczne (współfinansowane ze środków UE, dla której tego typu działania są istotnym priorytetem strategii Europa 2020) i prywatne, szczególnie w tych obszarach, w których zostały stworzone odpowiednie zachęty prawne i podatkowe. Jeżeli zatem realizacja unijnego planu - wbrew przytoczonym opiniom ekspertów ze świata energetyki - dojdzie do skutku, zmianie ulegnie zagospodarowanie przestrzenne kraju. W warunkach polskich do OZE o największym potencjale ekonomicznym należy zaliczyć energię wiatru, energię z biomasy i biogazu oraz energię geotermalną. Według KPZK 2030, minister środowiska, w porozumieniu z placówkami naukowymi i organizacjami ekologicznymi oraz branżowymi, ma przygotować wytyczne dotyczące rozwoju energetyki odnawialnej w różnych typach obszarów produkcji i wykorzystania OZE. Na poziomie planów zagospodarowania przestrzennego województw (PZPW) zostaną wyznaczone strefy zakazu wykorzystania lub ograniczonego rozwoju (wraz z określeniem rodzaju i zakresu tego ograniczenia) różnych form energetyki odnawialnej.

Ze względu na położenie geograficzne Polski oraz związanych z nim warunków klimatycznych przy obecnych możliwościach technologicznych mniejsze znaczenie będzie miała energia solarna. W polskim krajobrazie energetycznym zwiększy się udział farm wiatrowych. Zasadnicza część turbin będzie zlokalizowana na lądzie (ok. 90\%), w mniejszym stopniu będzie wykorzystana w tym zakresie przestrzeń morska. Ze względu na uwarunkowania klimatyczne najważniejsze farmy będą zlokalizowane na północy kraju, co w znacznym stopniu przyczyni się do rozwiązania problemu niedoinwestowania tego regionu w zakresie infrastruktury energetycznej. KPZK 2030 zakłada, że ewentualne konflikty powstałe na gruncie przestrzennego zagospodarowania terenu między potrzebą ochrony krajobrazu a potrzebami energetycznymi mają być minimalizowane przez system ustaleń planistycznych.

Jednakże rozproszona energia produkowana z OZE musi zostać wprowadzona do sieci, co stanowi pewną barierę, zwłaszcza finansową. Sieć przesyłowa wysokiego napięcia musi zostać rozbudowana, aby umożliwić przejęcie mocy m.in. z planowanych lądowych i morskich farm wiatrowych. Zadaniem planowania przestrzennego będzie wyznaczenie stref dla rozwoju energetyki wiatrowej (na poziomie zarówno krajowym, jak i wojewódzkim), określenie obszarów wykorzystania energii geotermalnej oraz lokalizacji wieloletnich plantacji roślin energetycznych (na poziomie PZPW), przy jednoczesnym ograniczeniu ich niekontrolowanej ekspansji na innych obszarach, zwłaszcza na terenach cennych ze względów przyrodniczych.

Istnieje zatem potrzeba rozbudowy polskiego systemu połączeń energetycznych, zarówno wewnętrznych, jak i z państwami sąsiednimi. W celu zapewnienia sprawnego funkcjonowania oraz bardziej równomiernego rozmieszczenia sieci przesyłowej energii elektrycznej (najwyższych napięć: 400 kV i $220 \mathrm{kV}$ ) nowe inwestycje wewnątrz kraju będą koncentrowały się szczególnie w północnej i wschodniej Polsce. W pierwszym etapie, do 2015 roku, mają powstać m.in. sieci przesyłowe najwyższego napięcia z Łomży do Ełku i w kierunku granicy państwa, z Ostrołęki do Olsztyna i Płocka oraz z Żydowa do Gdańska i Pelplina. W kolejnym okresie, do 2020 roku, linia z Ostrołęki zostanie przedłużona do Stanisławowa, a z Żydowa przez Piłę do miejscowości Plewiska. W tym okresie będą również budowane linie łączące Lublin z Chełmem i Lublin z Siedlcami. Natomiast po roku 2020 ciężar inwestycji w sieci 
wysokiego napięcia przesunie się na zachód od Wisły na kierunku północ-południe. Długość linii 400 kV wzrośnie, zmniejszy się natomiast długość linii 220 kV. Zostaną zwiększone również zdolności linii przesyłowych w kierunkach wschód-zachód i północ-południe.

$\mathrm{W}$ ramach rozbudowy połączeń z krajami sąsiednimi realizowane będą inwestycje zmierzające do powiązania polskiego systemu energetycznego z systemami energetycznymi przede wszystkim państw UE: Niemiec (Neuenhagen - Vierraden - Krajnik), Słowacji, Litwy (Ełk - Olita/ Alytus), a także z systemem energetycznym Ukrainy, a w dalszej perspektywie - Rosji i Białorusi. W dłuższym okresie (to znaczy po roku 2020) nastąpi także integracja ze skandynawskimi systemami energetycznymi w ramach realizacji tzw. Elektroenergetycznego Pierścienia Bałtyckiego (Niemcy - Polska - Białoruś - Rosja - Litwa - Łotwa - Estonia - Finlandia - Szwecja - Norwegia - Dania) (KPZK 2030).

$\mathrm{Z}$ punktu widzenia struktury polskiego przemysłu energetycznego efektem prowadzonej obecnie polityki klimatycznej niewątpliwie będzie zahamowanie rozwoju elektrowni węglowych, a konkurencyjne wobec nich staną się elektrownie jądrowe (Tajduś, Czaja, Kasztelewicz, 2011). Z czasem zyskają one przewagę, a będzie to zależało od popytu na energię, bezpieczeństwa dostaw węgla oraz cen uprawnień do emisji $\mathrm{CO}_{2}$, które wg Z. Kasztelewicza (Kasztelewicz, 2011) będą kształtować się na poziomie ok. 7-20 mld złotych rocznie w latach 2020-2050. Jeżeli te trzy zmienne zachowają poziom umiarkowany wzrost popularności energetyki jądrowej pojawi się dopiero za 20 lat. Wcześniej popyt będzie zaspokajany przez wdrażane instalacje energetyki odnawialnej. Konkurencją dla węgla stanie się również gaz, jednak elektrownie gazowe będą wykorzystywane raczej jako moce regulacyjne i wspomagające (Kasztelewicz, 2011).

Wobec nakreślonych powyżej założeń polityki energetycznej przedstawiciele sektora węglowego podejmują próby ratowania polskiej energetyki konwencjonalnej. Obecnie niektóre przedsiębiorstwa energetyczne świadomie inicjują przedsięwzięcia na rzecz utrzymania atrakcyjności sektora węglowego w obliczu restrykcyjnych wymogów unijnych. Dobrym przykładem jest projekt własnej elektrowni realizowany przez Kompanię Węglową na terenie dawnej kopalni Czeczott w Woli koło Pszczyny, która ma powstać do 2019 roku. Niewątpliwie jest to pozytywna inicjatywa w kontekście rozwoju energetyki konwencjonalnej, ponieważ eliminuje główną barierę inwestycyjną w nowe moce wytwórcze, ograniczając ryzyko wahań cen paliwa, która w tym przypadku będzie podlegała wewnętrznym ustaleniom zainteresowanych podmiotów. Dla Kompanii Węglowej ten projekt zapewnia zbyt na wydobywany węgiel w długoletnim horyzoncie czasowym, nawet do 25-30 lat. Warto wspomnieć, że Kompania Węglowa z końcem czerwca 2013 roku podpisała również list intencyjny z Grupą Kapitałową PGE w sprawie długoterminowych dostaw węgla do elektrowni w Opolu, która w przyszłości ma zostać rozbudowana o dwa nowe bloki. Na uwagę zasługują również działania marketingowe prowadzone przez Południowy Koncern Węglowy, który pod hasłem „Polski węgiel dla Ciebie” promuje sprzedaż polskiego węgla. Jest to ważne szczególnie w kontekście rosnącej konkurencyjności tego rynku.

Na wzrost atrakcyjności sektora węglowego mogą wpłynąć badania prowadzone przez ośrodki badawczo-rozwojowe. Czołowe polskie instytucje badawcze związane z energetyką węglową, m.in. Główny Instytut Górnictwa (GIG), Instytut Chemicznej Przeróbki Węgla 
(ICHPW) oraz Akademia Górniczo-Hutnicza (AGH) w Krakowie, od kilkudziesięciu lat pracują nad stworzeniem i implementacją różnych aplikacji związanych z nowoczesnymi czystymi technologiami wytwarzania energii elektrycznej na bazie paliw stałych. Warto wspomnieć, że wyżej wymienione instytucje wraz z partnerami środowisk przemysłowych są członkami europejskiej organizacji Knowledge \& Innovation Community (KIC) InnoEnergy, mającej na celu wsparcie integracji edukacji, technologii, biznesu i przedsiębiorczości oraz wzmocnienie kultury innowacji. Współpraca w zakresie wymiany osiągnięć naukowych w dziedzinie technologii węglowych posiada zatem wymiar międzynarodowy.

Czyste technologie węglowe (CTW) mogą skutecznie zmniejszyć emisję gazów cieplarnianych i pozwolić na ochronę polskiego sektora węglowego przed dekarbonizacją. Obecnie z wykorzystaniem środków unijnych Programu Operacyjnego Innowacyjna Gospodarka 2007-2013 realizowany jest projekt inwestycyjny pod nazwą Centrum Czystych Technologii Węglowych, w ramach którego powstały nowoczesne laboratoria oraz linie technologiczne. W celu zwiększenia efektywności realizacji tej idei postuluje się, aby oprócz finansowania przez Narodowe Centrum Badań i Rozwoju stworzony został system ulg podatkowych dla podmiotów działających w CTW, a także powołanie pełnomocnika rządu ds. rozwoju czystych technologii węglowych.

\section{ZŁAGODZENIE POLITYKI KLIMATYCZNEJ}

Prawdopodobnym scenariuszem jest złagodzenie polityki klimatycznej Unii Europejskiej w obliczu kryzysu ekonomicznego, który odsunie na dalszy plan kosztowne inwestycje redukujące emisję $\mathrm{CO}_{2}$. Cel emisyjny na 2020 rok może zostać odroczony na kolejne lata, a limity emisji będą podwyższane wraz ze spadkiem cen uprawnień emisyjnych, co niewątpliwie będzie szansą na utrzymanie wiodącej pozycji energetyki konwencjonalnej w Polsce. Skrajnie liberalna polityka klimatyczna może doprowadzić do całkowitego braku restrykcji na emisję $\mathrm{CO}_{2}$ lub zerowych cen uprawnień emisyjnych. W tej sytuacji pewna jest dominacja węgla kamiennego i brunatnego w strukturze zużycia paliw w polskiej energetyce, z uwagi na jego względnie niski koszt oraz wysoką wydajność energetyczną. Elektrownie węglowe będą przeżywać okres rozkwitu i osiągać wysokie wyniki finansowe, a kopalnie bez problemu znajdą klientów na wydobywany węgiel. Zerowe ceny uprawnień emisyjnych doprowadzą do sytuacji, w której elektrownie gazowe znajdą zastosowanie głównie jako turbiny o funkcjach regulacyjnych wykorzystywane w okresach szczytowych zużycia energii (Kasztelewicz, 2011). Udział gazu ziemnego w strukturze źródeł energii będzie kształtował się na poziomie ok. 5\%. Produkcja energii z OZE, biomasy oraz biogazu nie będzie wymu-

szana. Źródła te mogą stanowić jedynie afrodyzjak dla bogatszych wytwórców energii, ale jednocześnie zabezpieczenie na wypadek kryzysu w sektorze węglowym lub nagłej zmiany uregulowań dotyczących limitów emisyjnych. Bez polityki klimatycznej oraz zielonych certyfikatów na energię z OZE prawdopodobnie nie będzie konieczności odbudowywania elektrowni wiatrowych oraz instalacji biomasowych i biogazowych po zakończeniu ich 
eksploatacji. W sytuacji taniej energii z węgla i bezpieczeństwa dostaw tego paliwa nie wystąpi zaangażowanie kapitału w energetykę jądrową.

Pomijając kwestie dotyczące polityki klimatycznej, kryzys gospodarczy mógłby w skrajnym przypadku doprowadzić do zmniejszenia produkcji przemysłowej i konsumpcji, co spowodowałoby spadek zapotrzebowania na energię elektryczną. Mniejsze zużycie energii mogłoby przyczynić się do odroczenia problemu zagrożonego bezpieczeństwa energetycznego Polski. W tym kontekście kryzys gospodarczy mógłby okazać się zjawiskiem pozytywnym, jednak jego zaistnienie w tak drastycznej wersji wydaje się być mało prawdopodobne.

\section{ZAOSTRZENIE POLITYKI KLIMATYCZNEJ}

W sytuacji zaostrzenia polityki klimatycznej, czyli szybkiej dekarbonizacji, polski sektor węglowy będzie wypierany przez inne źródła energii, w szczególności przez OZE. Osiągnięcie tego efektu mogłoby zostać zapewnione poprzez uregulowania prawne poprawiające atrakcyjność inwestowania w instalacje wykorzystujące OZE, przy jednoczesnym obniżeniu rentowności elektrowni konwencjonalnych poprzez rosnące ceny uprawnień do emisji $\mathrm{CO}_{2}$. Dobrym przykładem instytucjonalno-prawnej zachęty do angażowania kapitału w projekty dekarbonizacyjne jest zatwierdzenie przez Parlament Europejski na początku lipca 2013 roku planu Komisji Europejskiej w sprawie tzw. blackloadingu, czyli przesunięcia 900 mln uprawnień do emisji $\mathrm{CO}_{2}$ dostępnych na aukcjach od początku trzeciego okresu rozliczeniowego na jego koniec. Działanie to ma na celu wzrost rynkowego poziomu cen uprawnień do emisji, a tym samym wsparcie inwestycji w technologie niskoemisyjne. Zawieszona pula uprawnień może ulec tzw. set-aside, czyli trwałemu wycofaniu z rynku.

Warto wspomnieć również o tzw. małym trójpaku energetycznym, czyli nowelizacji prawa energetycznego, który wszedł w polski porządek prawny z dniem 11 września 2013 roku (ustawa z dnia 26 lipca 2013 r. o zmianie ustawy Prawo energetyczne oraz niektórych innych ustaw). Ustawa ta ma na celu zapewnienie pełnej implementacji przepisów unijnych, promujących wykorzystanie energii ze źródeł odnawialnych. Ponadto reguluje wspólne zasady rynku wewnętrznego energii elektrycznej i gazu ziemnego. Jest to preludium tzw. dużego trójpaku, w skład którego wchodzą obecnie projekty ustaw: Prawo energetyczne, Prawo gazowe oraz ustawa o odnawialnych źródłach energii, które mają wspomóc szybkie wdrażanie do polskiego systemu prawnego unijnych dyrektyw energetycznych, w szczególności dyrektywy Parlamentu Europejskiego i Rady 2009/28/WE z dnia 23 kwietnia 2009 r. w sprawie promowania stosowania energii ze źródeł odnawialnych zmieniająca i w następstwie uchylająca dyrektywy 2001/77/WE oraz 2003/30/WE.

W projektowanej ustawie o OZE, której uchwalenie planowane jest do końca 2013 roku, atrakcyjnym dla potencjalnych inwestorów jest nowy sposób rozliczania produkcji zielonej energii wg systemu taryfy feed-in, która zakłada pewność zakupu tej energii przez zobowiązanego, za z góry określoną cenę, przez okres 15 lat liczony od dnia oddania instalacji 
do użytkowania (Szybalski, 2013). Ustalenie polityki cenowej w taki sposób z pewnością wpłynie niekorzystnie na swobodę działania popytu i podaży na rynku energii elektrycznej, faworyzując instalacje wykorzystujące OZE kosztem technologii konwencjonalnych. Ciekawym punktem planowanych zmian w obszarze OZE jest również polityka dotycząca świadectw pochodzenia, czyli zbywalnych praw majątkowych potwierdzających wytworzenie energii w odnawialnych źródłach energii. Nowe regulacje ustawowe mają zapobiec notowanemu w ostatnim czasie spadkowi cen zbywania zielonych certyfikatów. Minister gospodarki podejmie działania mające na celu zwiększenie udziału energii elektrycznej wytwarzanej z OZE w sprzedaży odbiorcom końcowym, w sytuacji gdy średnie ceny zbywania świadectw pochodzenia na giełdzie towarowej przez okres co najmniej dwóch kolejnych kwartałów będą niższe niż 75\% wartości opłaty zastępczej ${ }^{1}$. Przytoczone przykłady regulacji w planowanej ustawie o OZE z pewnością wpłyną na zmniejszenie ryzyka inwestycyjnego w sektorze energetyki odnawialnej, ale jednocześnie zniekształcą funkcjonowanie rynku energii, wypierając instalacje węglowe.

W celu obniżenia rentowności energetyki węglowej stopniowo będą podnoszone ceny zakupu uprawnień emisyjnych. Sektor węglowy poniesie również koszty związane z implementacją drogich technologii ograniczających emisję $\mathrm{CO}_{2}$. Elektrownie węglowe budowane będą jedynie do roku 2020, ze względu na brak w tym okresie innych alternatywnych jednostek produkujących energię w wystarczająco dużej skali. W późniejszych latach budowa elektrowni węglowych będzie opierała się na technologiach wyposażonych w CCS. Powszechnie wybierane będą również technologie polegające na zgazowaniu węgla. Ten proces technologiczny polega na przeprowadzeniu rozkładu termicznego paliwa stałego lub płynnego o dużej zawartości węgla, w wyniku którego powstaje paliwo gazowe. Zgazowanie jest jednym ze sposobów wykorzystania węgla i ma na celu przede wszystkim ograniczenie emisji $\mathrm{CO}_{2}$ (Okulski, 2012).

Według szacunków B. Jankowskiego (2011), łączne koszty dekarbonizacji dla polskiego sektora węglowego, zawierające zarówno koszty nowych technologii, jak i zakupów uprawnień emisyjnych, będą kształtować się na poziomie nawet ponad $120 \mathrm{mld}$ zł do roku 2050 (tab. 2).

Tab. 2. Szacowane koszty dekarbonizacji polskiego sektora węglowego w latach 2020-2050

\begin{tabular}{|c|c|}
\hline $\begin{array}{c}\text { Szacowane koszty dekarbonizacji } \\
\text { (w mld zł na rok) }\end{array}$ & Przedział czasowy \\
\hline $15-8$ & $2020-2030$ \\
\hline $41-43$ & $2030-2040$ \\
\hline $55-63$ & $2040-2050$ \\
\hline
\end{tabular}

Źródło: opracowanie własne na podstawie: Jankowski, 2011

${ }^{1}$ Opłata zastępcza - opłata ponoszona przez odbiorcę końcowego za nieprzedstawienie do umorzenia prezesowi Urzędu Regulacji Energetyki świadectwa pochodzenia w terminie do 31 marca każdego roku. 
Należy zaznaczyć, że jedynie koszty zakupu uprawnień emisyjnych, w przypadku wprowadzenia polityki głębokiej dekarbonizacji w Unii Europejskiej, wyniosą dla Polski ok. 10-60 mld zł rocznie w latach 2020-2050 (Kasztelewicz, 2011).

Polityka dekarbonizacji będzie sprzyjała wzrostowi udziału energetyki jądrowej oraz produkcji energii z OZE. Główną konkurencję dla elektrowni węglowych będą stanowić właśnie elektrownie jądrowe. Elektrownie gazowe przy wysokich cenach gazu będą konkurencyjne dla elektrowni węglowych przy umiarkowanie wysokich cenach uprawnień do emisji $\mathrm{CO}_{2}$. Elektrownie parowo-gazowe prawdopodobnie również zyskają na znaczeniu w okresie 2020-2030. W późniejszych latach, ze względu na wysokie ceny uprawnień do emisji, budowane będą wyłącznie elektrownie jądrowe albo węglowe z technologią CCS. Elektrowniom gazowym pozostanie rola bufora pracującego głównie w okresach szczytowych i podszczytowych zużycia energii. Jako naturalna konsekwencja polityki dekarbonizacji obserwowany będzie znaczny wzrost udziału OZE w produkcji energii, którego tempo będzie wzrastać wraz z rosnącymi cenami uprawnień do emisji $\mathrm{CO}_{2}$. Energetyka odnawialna, w szczególności energetyka wiatrowa, będzie coraz bardziej popularna (Kasztelewicz, 2011).

W skrajnym przypadku plan dekarbonizacji może zakładać redukcję gazów cieplarnianych na poziomie $80 \%$ w stosunku do emisji z roku 1990 w skali całej Unii Europejskiej. Wielce prawdopodobne jest również objęcie systemem zbywalnych uprawnień do emisji wszystkich podmiotów emitujących $\mathrm{CO}_{2}$. W sytuacji powszechnego eksploatowania małych źródeł energii konwencjonalnej prawdopodobne wydaje się także wprowadzenie dodatkowych opłat, np. podatku węglowego, aby przyspieszyć efekt dekarbonizacji. Tak restrykcyjna polityka klimatyczna w warunkach polskich może doprowadzić do degradacji gospodarki. Wdrożenie wymuszonych drogich technologii produkcji energii elektrycznej oraz rosnące ceny uprawnień emisyjnych spowodują ogromny wzrost kosztów działalności przedsiębiorstw energetycznych i w krótkim czasie przeniosą się na całą gospodarkę. Naturalną konsekwencją będzie wzrost kosztów produkcji towarów i usług oraz zrzucenie ich na konsumentów. W związku z tym sytuacja będzie miała znamiona silnie inflacjogenne. Według szacunków ESPON najbardziej narażone na inflację i ,ucieczkę” są branże energochłonne, to znaczy takie, dla których poziom kosztów energii przekracza $10 \%$ całkowitych kosztów działalności. W przypadku Polski dotyczy to znacznej części firm działających w przemyśle (górnictwo rud metali, wapienia, gipsu i kredy), przetwórstwie przemysłowym (zaprawy, cement, szkło, wapno), budownictwie (materiały konstrukcyjne i budowlane).

Przy założeniu powyższego scenariusza z pewnością nastąpi spadek PKB oraz wzrost stopy bezrobocia. Paradoksalnie, można stwierdzić, że w sytuacji kryzysu ekonomicznego i energetycznego nastąpi „ucieczka” przemysłu oraz wzrost migracji w celach zarobkowych, a tym samym spadnie zużycie energii elektrycznej. Zatem zmniejszy się zapotrzebowanie na inwestycje w OZE na polskim rynku, gdyż emisja $\mathrm{CO}_{2}$ spadnie po zajściu wspomnianych zjawisk.

Z drugiej strony, pod pewnymi warunkami stworzonymi przez odpowiednie prawa i instytucje, alokacja zasobów w sektorach technologii niskoemisyjnych z tytułu przeprowadzanej dekarbonizacji może spowodować rozwój innowacji, wzrost gospodarczy i powstawanie nowych miejsc pracy. Jednym z nich jest sektor produkcji urządzeń dla sektora energetycznego, 
w którym prognozowane jest powstanie nowych jednostek systemowych w technologiach skojarzonych, biogazowych oraz odnawialnych źródłach energii. Jednocześnie stworzy to konieczność rozbudowy odpowiedniej infrastruktury sieciowej, co przyniesie dodatkowe zyski producentom działającym w tej branży.

$\mathrm{Na}$ zwiększonych inwestycjach w polskiej energetyce mogą skorzystać również konsumenci indywidualni. W warunkach dekarbonizacji na znaczeniu będzie zyskiwać energetyka rozproszona, w tym energetyka domowa (indywidualne instalacje fotowoltaiczne i wiatrowe). Rozbudowana infrastruktura sieciowa zostanie wyposażona w inteligentne liczniki energii, które umożliwią rozliczanie wytworzonej energii elektrycznej oraz - poprzez możliwość zdalnego i ciągłego monitorowania produkcji i zużycia - będą wspierać oszczędność i wzrost efektywnego wykorzystania energii.

Polityka dekarbonizacji może wpłynąć na rozwój firm budowlano-montażowych, które będą miały znaczący udział w zwiększonych nakładach inwestycyjnych. Należy wspomnieć, że zasadnicza część Krajowego Planu Działań dotyczącego efektywności energetycznej (EEAP) odnosi się do sektora mieszkalnictwa, gdzie firmy budowlano-montażowe będą realizować m.in. oceny energetyczne budynków wysoce energooszczędnych oraz przedsięwzięcia termomodernizacyjne dla budynków mieszkalnych.

Zwiększenie udziału energii z OZE spowoduje także rozwój rolnictwa energetycznego. W Polsce największy potencjał w tym zakresie dotyczy biomasy leśnej (m.in. drzewo odpadowe w leśnictwie i przemyśle drzewnym) oraz rolnej (m.in. produkty uboczne i odpadowe rolnictwa i przemysłu rolno-spożywczego). Ze względu na ograniczenia w stosowaniu biomasy pochodzenia leśnego przewidywany jest znaczący wzrost popytu na biomasę pochodzenia rolniczego. Istotnym elementem kształtującym rozwój upraw energetycznych w Polsce będą dopłaty i mechanizmy wsparcia oraz stabilność przepisów prawnych.

Zaostrzony pakiet energetyczny przyczyni się do rozwoju usług w obszarze pozyskiwania oraz przetwarzania biomasy i paliw. Przykładowo, biomasa w stanie surowym może zostać poddana procesowi przerobu technologicznego w celu poprawienia jej cech fizyko-chemicznych ułatwiających transport i spalanie. Obecnie biomasa stała, przeznaczona do spalania w elektrowniach i elektrociepłowniach, podlega najczęściej kruszeniu, brykietowaniu lub peletowaniu. Ciągle w fazie badań w Polsce pozostają technologie zgazowywania biomasy lub jej uwęglania. Wraz z rozwojem przetwarzania biomasy wzrośnie też zapotrzebowanie na usługi magazynowe i logistyczne.

Dekarbonizacja może okazać się korzystna, jednakże w dalekiej przyszłości. Wcześniej jednak wymagać będzie poniesienia kosztów ex ante, które nie będą równomiernie rozłożone w czasie i nie będą zależeć ani od zamożności państwa, ani od jego wkładu w zmniejszenie emisji gazów cieplarnianych. Ogromne koszty dekarbonizacji związane z inwestycjami w nowe technologie, przebudową przemysłu energetycznego i ciepłowniczego, zwiększoną ekspozycją na ryzyko utraty bezpieczeństwa energetycznego, ryzykiem utraty konkurencyjności cenowej, miejsc pracy oraz z innymi społecznymi i ekonomicznymi zjawiskami wywołanymi przez wypieranie sektora węglowego są silnymi politycznymi argumentami. Dodatkowo nadal nie są one równoważone zwiększającą się świadomością ekologiczną 
wśród społeczeństwa, które niechętnie zaakceptuje pogorszenie obecnych warunków życia na rzecz ich niepewnej i niewielkiej poprawy dla przyszłych pokoleń (Płaziak, 2013b).

\section{Podsumowanie}

Odgrywanie przez Unię Europejską istotnej roli w międzynarodowej polityce klimatycznej, poprzez instrumentarium regulacji klimatycznych, wymaga niezwykle kosztownych działań obciążających bezpośrednio gospodarki państw członkowskich, zwłaszcza tych opierających swoją energetykę na paliwach stałych. Jednocześnie skuteczność tej polityki jest sporna - warto zwrócić uwagę na statystyki dotyczące zmian emisyjnych poszczególnych państw, które mogą być dowodem na słabe jej oddziaływanie na jakość powietrza. Całkowite emisje od roku referencyjnego, czyli 1990 lub 1995 w zależności od rodzaju gazu, wzrosły aż o ok. 50\%, a największy udział w tym wzroście mają Chiny i Indie, które zwiększyły emisje odpowiednio o ok. 276\% i 209\%. Poza Europą wszystkie regiony świata zwiększyły swoje emisje od ok. 177\% (Azja, region Pacyfiku) do ok. 14\% (Ameryka Północna). W Europie zaś - zgodnie z realizowaną polityką klimatyczną - emisje gazów cieplarnianych spadły o ok. 18,5\%. Interesujący jest fakt, że większość tej redukcji została osiągnięta dzięki krajom Europy Środkowo-Wschodniej (Polsce - 35\%, Rumunii - 74\%, Bułgarii $50 \%$, Litwie - 56\%), jako efekt uboczny poważnego spadku koniunktury oraz drastycznej transformacji struktury przemysłu w tych krajach. Spośród tzw. starych państw UE jedynie Niemcy, Francja, Wielka Brytania, Dania i Szwecja były w stanie zredukować emisje poniżej poziomu wskazanego w Protokole z Kioto. Pozostałe państwa z tej grupy, szczególnie te wyróżniające się dobrą koniunkturą gospodarczą, nie były w stanie pogodzić rozwoju ekonomicznego z redukcją emisji gazów cieplarnianych (Hiszpania - wzrost o 48\%, Irlandia wzrost o $37 \%$, Holandia - wzrost o $20 \%$ ). Zatem rodzi się pytanie, czy polityka klimatyczna UE w ogóle ma sens w świetle aktualnej sytuacji gospodarki unijnej oraz nieprzestrzegania limitów emisyjnych przez resztę świata (Szlagowski, 2012).

Polityka klimatyczna Unii Europejskiej wydaje się być raczej grą interesów niż faktyczną troską o dobro środowiska naturalnego. Istnieją grupy inwestorów oraz gałęzie przemysłu europejskiego, które - ufając unijnym planom dekarbonizacyjnym - zainwestowały w OZE olbrzymi kapitał, który obecnie chcą odzyskać. Samodzielna polityka klimatyczna Unii Europejskiej pogłębia różnice w rozwoju ekonomicznym między unijnymi krajami, obciążając kosztami jedne kraje, a dając jednocześnie możliwość czerpania zysków przez inne (Knap, 2013). Polska znalazła się w grupie krajów, które ponoszą największe koszty polityki klimatycznej, ze względu na dominującą rolę sektora węglowego w przemyśle energetycznym. W zależności od wspomnianych wariantów - złagodzenia polityki, kontynuacji lub dekarbonizacji, nakłady inwestycyjne będą kształtować się w różny sposób (tab. 3). 
Tab. 3. Szacowana wysokość nakładów inwestycyjnych do 2050 roku w zależności od wariantu polityki klimatycznej UE

\begin{tabular}{|l|l|}
\hline Wariant polityki klimatycznej & $\begin{array}{c}\text { Nakłady inwestycyjne do 2050 roku } \\
\text { (w mld zł) }\end{array}$ \\
\hline łagodna polityka & 300 \\
\hline kontynuacja polityki & 500 \\
\hline polityka dekarbonizacji & 600 \\
\hline
\end{tabular}

Źródło: opracowanie własne na podstawie: Kasztelewicz, 2011

Na podstawie przytoczonych powyżej szacunków wyraźnie widać, że polityka klimatyczna dwukrotnie zwiększa nakłady na źródła produkcji energii w Polsce, które będą rosnąć stopniowo i dotkliwie ujawnią się dopiero po 2015 roku.

Rozwój infrastruktury energetycznej będzie w perspektywie roku 2030 musiał sprostać wielu wyzwaniom:

- dążenie do redukcji zagrożenia braku płynności zaopatrzenia w ropę naftową i gaz ziemny poprzez działania na rzecz dywersyfikacji źródeł dostaw nośników energii (w sensie technicznym i geopolitycznym) oraz integrację systemów energetycznych (linii przesyłowych, gazociągów i rurociągów) z sieciami krajów sąsiednich, dzięki budowie połączeń transgranicznych,

- ograniczenie emisji $\mathrm{CO}_{2}$ do poziomu uzgodnionego w ramach UE poprzez m.in. wspieranie działań inwestycyjnych w różnych skalach przestrzennych (od elektrowni jądrowych o zerowym lub niskim poziomie emisji $\mathrm{CO}_{2}$ po obiekty przydomowe), dostosowanie sieci elektroenergetycznych do odbioru energii ze źródeł rozproszonych wykorzystujących OZE (przejęcie nadwyżek mocy z tych źródeł, w tym z planowanych lądowych i morskich farm wiatrowych, będzie wymagać budowy kilkuset kilometrów nowych linii przesyłowych wraz z infrastrukturą wspomagającą),

- bardziej równomierne rozmieszczenie elektrowni na terenie kraju oraz sieci przesyłowych energii elektrycznej i gazu,

- rozbudowa sieci przesyłowej niskiego napięcia niezbędnej do przyłączenia nowych źródeł wytwórczych, w tym OZE, i wyprowadzenia z nich mocy,

- poprawa efektywności przesyłu, zaopatrzenia i zużycia energii poprzez rozwój inteligentnych sieci przesyłowych (smart grids),

- ochrona złóż surowców o charakterze strategicznym, nawet jeżeli w najbliższych latach nie przewiduje się ich eksploatacji - dotyczy to zwłaszcza węgla kamiennego i brunatnego.

Polska powinna w miarę swoich możliwości rozwijać produkcję energii pochodzącej z OZE, ponieważ z punktu widzenia bezpieczeństwa energetycznego bardzo ważna jest dywersyfikacja źródeł. Należy jednak mieć na względzie fakt, że wpływ OZE na bilans mocy jest niewielki. Bezpieczeństwo energetyczne wymaga zapewnienia ciągłości zasilania, szczególnie w okresach największego zużycia energii elektrycznej (w godzinach wieczornych w miesiącach zimowych), czyli w czasie, gdy panele słoneczne nie działają, wiatry wieją sporadycznie, a praca biogazowni jest uzależniona od zgromadzonych wcześniej zapasów 
paliwa. Moce wytwórcze muszą charakteryzować się wysoką dyspozycyjnością, a taką mogą zapewnić jedynie technologie jądrowe, gazowe i węglowe. Energetyka jądrowa w panujących obecnie w Polsce warunkach ciągle wydaje się nieosiągalna, ze względu na wysokie koszty i brak akceptacji społeczeństwa. Złoża gazu występują w ograniczonych ilościach, a dodatkowo nie ma jak dotąd opracowanego planu działania dotyczącego jego wydobycia i eksploatacji. Wydaje się zatem, że w ciągu najbliższych lat dominującym paliwem w polskiej energetyce pozostanie węgiel, dla którego kryzys gospodarczy - wymuszający ewentualne złagodzenie polityki klimatycznej UE - może okazać się zbawienny, przynajmniej w najbliższej perspektywie czasowej.

Dyskusja o możliwych wariantach międzynarodowej polityki klimatyczno-energetycznej jawi się jako konieczna z punktu widzenia rocznej prezydencji Polski w ogólnoświatowej konwencji klimatycznej. Prezydencja ta rozpoczęła się Konferencją Stron UNFCCC COP19 w Warszawie w dniach 11-22 listopada 2013 roku jako IX Spotkanie Stron Protokołu z Kioto. Najważniejszy cel szczytu to wypracowanie fundamentów pod nowe międzynarodowe porozumienie klimatyczne w sprawie redukcji emisji gazów cieplarnianych, które zacznie obowiązywać od 2020 roku. Prezydencja Polski może stać się okazją do wzmocnienia polskiego stanowiska oraz szansą na przeforsowanie regulacji korzystnych dla polskiego przemysłu energetycznego. Stanowczo nie można zgodzić się na równe traktowanie i proporcjonalne ustalanie zobowiązań finansowych krajów wg bieżącego poziomu emisji gazów cieplarnianych. Taka sytuacja będzie stawiała na straconej pozycji kraje rozwijające się, ponieważ kraje wysoko rozwinięte zrekompensują sobie koszty uprawnień zwiększoną sprzedażą urządzeń lub technologii związanych z ograniczaniem emisji gazów cieplarnianych. W najgorszej sytuacji znajdą się kraje o dużym udziale węgla w produkcji energii (m.in. Polska), w których mechanizmy rekompensujące nie zapewniają utrzymania tempa umożliwiającego odrabianie strat w poziomie rozwoju gospodarczego. Najlepszym dla Polski oraz innych krajów rozwijających się rozwiązaniem w kwestii ustalania limitów emisyjnych byłoby uwzględnienie historycznych, łącznych antropogenicznych emisji per capita. Przy takim podejściu takie kraje, jak Chiny i USA, musiałyby natychmiast i drastycznie zredukować swoje emisje niemal całkowicie, co jednak wydaje się zabiegiem niemożliwym, ponieważ wiązałoby się to z likwidowaniem jednostek wytwórczych i gospodarczymi szokami. W przypadku rozciągnięcia tego procesu w czasie, doprowadziłoby to do emisji znaczącej ilości dodatkowych gazów cieplarnianych do atmosfery przez kraje rozwijające się. Dlatego jedynym racjonalnym rozwiązaniem jest wykorzystywanie wspólnych możliwości oraz solidarność w ponoszeniu kosztów dekarbonizacji pomiędzy uczestnikami międzynarodowej konwencji klimatycznej.

\section{Literatura \\ References}

Dyrektywa Parlamentu Europejskiego i Rady 2010/31/UE z dnia 19 maja 2010 roku w sprawie charakterystyki energetycznej budynków, Dz.U. L 153 z 18 czerwca 2010 roku.

Dyrektywa Parlamentu Europejskiego i Rady 2009/28/WE z dnia 23 kwietnia 2009 roku w sprawie promowania stosowania energii ze źródeł odnawialnych zmieniająca i w następstwie uchylająca dyrektywy 2001/77/WE oraz 2003/30/WE, Dz.U. L 140 z 5 czerwca 2009 roku. 
Ferudun, D., Wilczyński, P.L. (2013). The Similarity Analysis of industrial development in EU Countries and Turkey Using Hierarchical Cluster Technique. Prace Komisji Geografii Przemystu Polskiego Towarzystwa Geograficznego, 21, 316-326.

Hermann, E. Ott (1998). The Kyoto protocol. Unfinished business. Environment, 40 (6, Jul/Aug), 16-20. Jankowski, B. (2011). Wizja polskiego sektora energetycznego w perspektywie europejskiej polityki dekarbonizacji. Materiaty Szkoły Eksploatacji Podziemnej „EnergSys” Sp. z o.o 2011. Kraków: PAN IGSMiE.

Kasztelewicz, Z. (2011). Wpływ polityki klimatycznej UE na górnictwo i energetykę Polski. Zeszyty Naukowe Instytutu Gospodarki Surowcami Mineralnymi i Energia PAN, 81, 147-163.

Knap, W. (2013, 6 marca). Stracimy miliardy? Co najmniej 20 procent pieniędzy UE na lata 2014-2020 musi zostać przeznaczonych na cele klimatyczne. Dziennik Polski.

Komunikat Komisji do Rady Europejskiej i Parlamentu Europejskiego, Europejska polityka energetyczna. (2007). Bruksela.

Koncepcja przestrzennego zagospodarowania kraju 2030. (2012). Warszawa: Ministerstwo Rozwoju Regionalnego.

Konkluzje Rady Europejskiej (2007, 9 marca). 7224/07. Bruksela.

Konkluzje Rady Europejskiej (2011, 8 marca). EUCO 2/1/11, REV 1, CO EUR 2, CONCL 1. Bruksela.

Kyoto Protocol to the United Nations Framework Convention on Climate Change. (1998). United Nations.

Okulski, T. (2012). Upłynnianie i zgazowanie węgla sposobem na jego wykorzystanie w silnikach spalinowych i w energetyce. Rynek energii, 4, 86-93.

Płaziak, M. (2013a). Technologia tanich domów energooszczędnych jako odpowiedź na kryzys w budownictwie mieszkaniowym. Przedsiębiorczość - Edukacja, 9.

Płaziak, M. (2013b). Domy energooszczędne i pasywne jako nieunikniona przyszłość budownictwa w Polsce. Prace Komisji Geografii Przemystu Polskiego Towarzystwa Geograficznego, 21, 173-188.

Rachwał, T. (2008). Problematyka badawcza funkcjonowania przedsiębiorstw przemysłowych. Prace Komisji Geografii Przemystu Polskiego Towarzystwa Geograficznego, 11, 53-85.

Strategia Europa 2020 (2015, 1 kwietnia). Pozyskano z http://ec.europa.eu/europe2020/index_pl.htm

Szlagowski, P. (red.) (2012). W stronę nowego klimatycznego kompromisu dla konkurencyjności europejskiej gospodarki - szanse i wyzwania pakietu energetyczno-klimatycznego Unii Europejskiej. Kraków: Dante Media, Instytut Kościuszki.

Szybalski, K. (2013). Kto zarobi na nowej ustawie o odnawialnych źródłach energii? Energetyka, 315. Tajduś, A., Czaja, P., Kasztelewicz, Z. (2011). Rola węgla w energetyce i strategia polskiego górnictwa węgla brunatnego w I połowie XXI wieku. Górnictwo i Geoinżynieria, 35 (3), 343-365.

United Nations Framework Convention on Climate Change. (1992).United Nations.

Ustawa z dnia 26 lipca 2013 r. o zmianie ustawy Prawo energetyczne oraz niektórych innych ustaw. Dz.U. z 2013 r., poz. 984.

Zielona księga. (2015, 1 kwietnia). Pozyskano z http://ec.europa.eu/green-papers/

Zioło, Z. (2008). Problemy badawcze struktury przestrzennej przemysłu. Prace Komisji Geografii Przemystu Polskiego Towarzystwa Geograficznego, 11, 9-25.

Patryk Dunal, student Uniwersytetu Ekonomicznego w Krakowie na kierunku finanse i rachunkowość, oraz Politechniki Krakowskiej na kierunku zarządzanie i inżynieria produkcji. Stypendysta Prezesa Rady Ministrów (2009). Laureat X miejsca olimpiady języka rosyjskiego (2009). Praktykant w firmie Tauron Dystrybucja S.A., Głównym Instytucie Górnictwa oraz BDO Sp. z o.o. Uczestnik Akademii Rachunkowości organizowanej przez firmę Deloitte. Wyróżniony w konkursie „Letnie Igrzyska Rachunkowości” organizowanym przez Stowarzyszenie Księgowych w Polsce. Zainteresowania naukowe autora koncentrują się na finansach w energetyce oraz ocenie efektywności projektów inwestycyjnych i analizie finansowej. 
Patryk Dunal is a student at the Cracow University of Economics in the Faculty of Finance and Accounting, and at the Cracow University of Technology, in the Faculty of Management and Production Engineering. In 2009 he received a scholarship of the Prime Minister and finished 10th in the Russian Language Olympiad. He is also a trainee in Tauron Distribution; Central Mining Institute; and BDO, as well as a participant of the Accounting Academy, organized by Deloitte. He received an award in "Summer Accounting Games" organized by the Accountants' Association in Poland. The author is interested in finance in the energy industry, assessment of the effectiveness of investment projects, and financial analysis.

Monika Plaziak, dr, adiunkt w Zakładzie Przedsiębiorczości i Gospodarki Przestrzennej, Instytut Geografii, Uniwersytet Pedagogiczny w Krakowie. Studia magisterskie i doktoranckie ukończyła w Instytucie Geografii i Gospodarki Przestrzennej Uniwersytetu Jagiellońskiego. Zainteresowania badawcze autorki dotyczą zagadnień gospodarki przestrzennej w kontekście zrównoważonego rozwoju - miast zrównoważonych społecznie i miast energooszczędnych, a także lokalizacji przedsiębiorstw, zwłaszcza przemysłowych i budowlanych. Prace badawcze odnoszą się również do zagadnień współpracy jednostek naukowych i badawczo-rozwojowych z sektorem MŚP, głównie w zakresie wdrażania nowych technologii i materiałów, w tym dotyczących budownictwa energooszczędnego i pasywnego. Ponadto autorka zajmuje się problematyką poziomu i jakości życia ludności, ze szczególnym uwzględnieniem małych i średnich miast Polski.

Monika Plaziak, Ph.D., is an assistant professor in the Department of Entrepreneurship and Spatial Management, Institute of Geography, the Pedagogical University of Cracow. She graduated from the Jagiellonian University in Krakow and got her Ph.D., degree in economic geography (at the Jagiellonian University in Krakow), Research interests of the author concern issues of spatial development in the context of sustainable development - socially balanced towns and energy-efficient towns, and also the locating of industrial and construction enterprises. Additionally, her research works include the cooperation of scientific and R\&D organizations with the SME sector, especially in the area of implementing new technologies and materials concerning the energy-efficient and passive building. Moreover, the author analyses issues of the level and quality of life, with particular focus on small and medium-sized towns in Poland.

\section{Adres/address:}

Uniwersytet Ekonomiczny w Krakowie

Wydział Finansów

ul. Rakowicka 27, 31-510 Kraków, Polska

e-mail: patrykdunal@gmail.com

Uniwersytet Pedagogiczny w Krakowie

Instytut Geografii

Zakład Przedsiębiorczości i Gospodarki Przestrzennej

ul. Podchorążych 2, 30-084 Kraków, Polska

e-mail: mplaziak@up.krakow.pl 